\title{
Pengembangan instrumen diagnostik three-tier untuk mengidentifikasi miskonsepsi materi fluida statis pada siswa kelas X MIA
}

\author{
Anisa Matinu Saifullah, Wartono*, Sugiyanto \\ Universitas Negeri Malang, Jl. Semarang No. 5 Malang, Jawa Timur, Indonesia \\ *Penulis korespondensi, Surel: wartono.fmipa@um.ac.id
}

Paper received: 01-07-2021; revised: 15-07-2021; accepted: 31-07-2021

\begin{abstract}
The researcher do research about development and application of three-tier diagnostic instrument to identify misconceptions within static fluid material. This research is due to research and development. The subject of the research is the student of $10^{\text {th }}$ grade of mathematics and science 4 MAN 3 Malang. The instrument is three-tier diagnostic instrument that consist of 24 questions with 4 alternative answers, 4 alternative reasons, and the sureness of every answer (sure/not sure) with three different levels. The material, construction, language, and misconception identificational ability on every question are valid according to experts judgement with average score over 3,26. Identification's result shows that many students still get in misconception on understanding the static fluid material, even some of them don't understand at all. Sort of misconception's types that found are student belief that (1) area of the container has an effect on hydrostatic pressure, (2) force given to the fluid will be transferred in all direction propotionally, (3) Archimedes's force is influenced by the depth of object on fluid.
\end{abstract}

Keywords: three-tier diagnostic instrument; misconceptions; static fluid.

\begin{abstract}
Abstrak
Peneliti melakukan penelitian pengembangan dan penggunaan instrumen diagnostik three-tier dengan tujuan untuk megidentifikasi miskonsepsi yang dimiliki siswa pada materi fluida statis. Penelitian yang dilakukan merupakan penelitian pengembangan. Subjek penelitian dalam penelitian adalah siswa kelas X MIA 4 MAN 3 Malang. Instrumen yang dikembangkan adalah instrumen diagnostik three-tier berjumlah 24 butir soal dengan 4 alternatif jawaban, 4 alternatif alasan pemilihan jawaban, dan keyakinan jawaban (yakin / tidak yakin) dengan 3 rentang tingkat keyakinan. Seluruh butir soal dinyatakan layak pada ranah materi, konstruksi, bahasa, dan kemampuan identifikasi miskonsepsi menurut penilaian ahli dengan nilai rata-rata diatas 3,26. Hasil identifikasi menunjukkan bahwa siswa yang mengalami miskonsepsi dan bahkan tidak memiliki konsepsi pada materi fluida statis masih cukup besar. Beberapa jenis miskonsepsi yang ditemukan diantaranya, siswa beranggapan bahwa (1) luas bejana mempengaruhi besarnya tekanan hidrostatis, (2) gaya yang diberikan pada fluida akan diteruskan ke segala arah sama besar, (3) gaya Archimedes dipengaruhi kedalaman benda dalam fluida.
\end{abstract}

Kata kunci: instrumen diagnostik three tier; miskonsepsi; fluida statis.

\section{Pendahuluan}

Siswa telah memiliki barisan pengalaman yang luas yang membentuk pengetahuan ilmiahnya, ketika mereka datang ke sekolah untuk belajar (Smith \& Abell, 2008). Pengetahuan awal yang diperoleh siswa dari pengalaman hidupnya disebut dengan istilah konsepsi. Konsepsi ini dapat diperoleh siswa melalui pengalaman belajar pada tingkat pendidikan sebelumnya, membaca buku, melihat televisi atau internet, serta mungkin dari fenomenafenomena di lingkungan sekitar (Smith \& Abell, 2008). Konsepsi yang telah dibangun oleh siswa belum tentu dianggap sesuai menurut pandangan masyarakat ilmiah. Konsepsi siswa yang tidak sesuai dengan pandangan masyarakat ilmiah dan digunakan oleh siswa secara konsisten disebut dengan istilah miskonsepsi (Demirci, 2005). Miskonsepsi dapat terjadi 
karena siswa membangun pemahaman mereka berdasarkan pengetahuan awal yang kurang memadai, sehingga konstruksi mereka berbeda dengan yang dimiliki guru (Barke et al. 2009).

Fisika merupakan salah satu mata pelajaran yang menggunakan pola pikir induktif serta selalu mengkaji materi melalui fenomena alam, sehingga miskonsepsi akan lebih mudah terjadi pada diri siswa. Salah satu materi yang banyak dijumpai dalam kehidupan sehari-hari adalah fluida statis, sehingga siswa sering berhubungan langsung dalam setiap aktivitasnya. Hal ini dapat membawa dampak miskonsepsi pada siswa jika konsepsi dan pemahamannya melalui pengalaman yang diperoleh hanya sepotong-sepotong. Penelitian tentang miskonsepsi fluida statis diantaranya dilakukan oleh Goszewski et al (2012) dan Wagner et al (2013).

Miskonsepsi perlu diidentifikasi sedini mungkin. Miskonsepsi yang telah dimiliki siswa dan mendarah daging dalam pemikirannya akan digunakan siswa sebagai landasan dalam mempelajari konsepsi selanjutnya. Salah satu cara yang dapat digunakan untuk mengidentifikasi miskonsepsi adalah penggunaan instrumen diagnostik Three-tier. Tes diagnostik Three-tier merupakan tes pilihan ganda yang terdiri dari tiga tahap (tier) pilihan. Tier pertama berisi sejumlah pilihan jawaban, tier kedua berisi sejumlah pilihan alasan untuk jawaban yang dipilih tersebut, sedangkan tier ketiga menunjukkan keyakinan siswa terhadap jawaban yang telah diberian. Dengan demikian tes diagnostik Three-tier memiliki kelebihan dibandingkan dengan tes pilihan ganda biasa.

Berdasarkan uraian di atas, peneliti bermaksud melakukan penelitian dengan judul "Pengembangan Instrumen Diagnostik Three-tier Untuk Mengidentifikasi Miskonsepsi Materi Fluida Statis Pada Siswa Kelas X MIA".

\section{Metode}

Penelitian pengembangan ini dirancang untuk memperoleh suatu produk. Produk yang dikembangkan adalah sejumlah butir soal pilihan ganda three-tier untuk mengidentifikasi miskonsepsi siswa kelas X MIA pada materi fluida statis. Subjek penelitian adalah 26 siswa kelas X MIA 4 MAN 3 Malang tahun ajaran 2014/2015. Instrumen yang digunakan dalam penelitian berupa instrumen diagnostik three-tier yang terdiri dari 24 butir soal. Pilihan jawaban dan alasan pada butir soal instrumen diagnostik three-tier diperoleh dari tes uraian terhadap 81 siswa. Sebelum instrumen diagnostik three-tier digunakan, divalidasi isi oleh dosen ahli terlebih dahulu.

Prosedur penelitian dan pengembangan ini terdiri dari empat tahap utama yaitu; analysis, desain, develop, dan Implement yang mana merujuk berdasarkan model pengembangan ADDIE. Jenis data yang diperoleh dari hasil uji coba instrumen diagnostik three-tier adalah berupa konsepsi yang ada dalam pikiran siswa. Konsepsi tersebut akan diklasifikasikan sesuai kategori yang telah ditentukan, kemudian dapat diidentifikasi kondisi konsepsi siswa tersebut. Siswa akan digolongkan pada empat kondisi konsepsi yaitu siswa yang memiliki konsepsi benar, siswa yang lemah dalam penguasaan konsepsi, siswa yang mengalami miskonsepsi, dan siswa yang tidak memiliki konsepsi. Selain itu hasil uji coba juga digunakan untuk mengidentifikasi jenis miskonsepsi pada materi fluida statis. 


\section{Hasil dan Pembahasan}

\subsection{Pengembangan Instrumen Diagnostik Three-Tier}

Proses pengembangan diawali dengan melakukan studi pendahuluan. Berdasarkan hasil studi pendahuluan baik pada studi kepustakaan maupun studi lapangan menunjukkan bahwa siswa masih mengalami miskonsepsi pada materi fluida statis. Beberapa miskonsepsi yang ditemukan adalah siswa masih salah dalam menentukan kedalaman benda dan siswa beranggapan bahwa gaya Archimedes dipengaruhi kedalaman benda dalam fluida.

Instrumen uraian dikembangkan sebanyak 13 butir soal dengan tujuan untuk mengetahui miskonsepsi yang sering dialami siswa, yang kemudian digunakan dalam mengembangkan instrumen diagnostik three-tier. Instrumen uraian divalidasi terlebih dahulu sebelum dilakukan uji coba. Hasil validasi disajikan pada Tabel 1.

Tabel 1. Hasil validasi instrumen uraian

\begin{tabular}{l|l|l|l}
\hline No & Ranah & $\begin{array}{l}\text { Rentangan Nilai } \\
\text { Rata-rata }\end{array}$ & Keeterangan \\
\hline 1 & Materi & $3,3-3,8$ & Layak \\
\hline 2 & Konstruksi & $3,3-3,8$ & Layak \\
\hline 3 & Bahasa & $3,4-3,6$ & Layak \\
\hline
\end{tabular}

Hasil uji coba instrumen uraian digunakan sebagai dasar dalam menentukan konsepsi dan miskonsepsi yang digunakan dalam mengembangkan produk instrumen diagnostik three-tier. Instrumen ini dikembangkan dari 8 indikator yang masing-masing indikator terdapat 24 butir soal. Butir soal dalam instrumen diagnostik three-tier disajikan dalam Tabel 2.

Tabel 2. Butir Soal dalam Instrumen Diagnostik Three-Tier pada Satu Indikator

Indikator : menjelaskan tekanan hidrostatis dipengaruhi kedalaman benda.

Jika disajikan gambar 5 titik di dalam bejana berhubungan yang berisi air, siswa dapat menjelaskan tekanan hidrostatis pada fluida sebanding dengan kedalaman titik yang diukur dari permukaan fluida. Sebuah bejana berhubungan memiliki bentuk yang berbeda-beda berisi air seperti gambar dibawah.

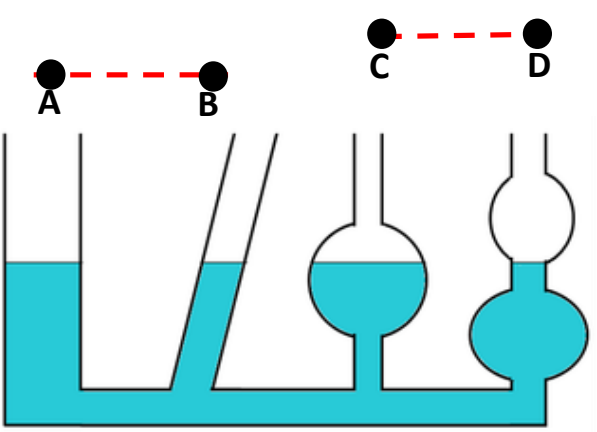

Pernyataan berikut yang tepat adalah...

tekanan hidrostatis di titik B paling besar dibandingkan dengan tekanan hidrostatis di titik A, C, dan D $\left(m_{3}\right)$

tekanan hidrostatis di titik $\mathrm{C}$ paling besar dibandingkan dengan tekanan hidrostatis di titik A, B, dan D $\left(m_{2}\right)$

tekanan hidrostatis di titik $\mathrm{C}$ dan $\mathrm{D}$ sama besar serta lebih besar dari pada tekanan hidrostatis di titik A dan B $\left(m_{1}\right)$ 


\begin{tabular}{|c|c|}
\hline & $\begin{array}{l}\text { tekanan hidrostatis di titik A dan B sama besar serta lebih besar } \\
\text { dari pada tekanan hidrostatis di titik C dan D }(k) \\
\text { Alasan: } \\
\text { Tekanan hidrostatis berbanding lurus dengan luas wadah fluida, } \\
\text { sehingga semakin besar luas wadah maka tekanan hidrostatis } \\
\text { semakin besar pula. }\left(m_{2}\right) \\
\text { Tekanan hidrostatis berbanding terbalik dengan luas wadah fluida, } \\
\text { sehingga semakin kecil luas wadah maka tekanan hidrostatis } \\
\text { semakin besar. }\left(m_{3}\right) \\
\text { Tekanan hidrostatis sebanding dengan kedalaman benda di ukur } \\
\text { dari permukaan fluida, semakin besar kedalamannya maka tekanan } \\
\text { hidrostatis semakin besar pula. }(k) \\
\text { Tekanan hidrostatis sebanding dengan kedalaman benda di ukur } \\
\text { dari dasar wadah, semakin besar kedalamannya maka tekanan } \\
\text { hidrostatis semakin besar pula. }\left(m_{1}\right) \\
\text { Apakah anda yakin? } \\
\text { Yakin } \\
\text { Tidak yakin } \\
\text { Berapa besar keyakinan anda? } \\
10-7 \\
6-4 \\
3 \text {-0 }\end{array}$ \\
\hline $\begin{array}{l}\text { Jika disajikan } 4 \\
\text { kondisi benda } \\
\text { yang berbeda- } \\
\text { beda dalam zat } \\
\text { cair, siswa } \\
\text { dapat } \\
\text { menentukan } \\
\text { besarnya } \\
\text { tekanan } \\
\text { hidrostatis } \\
\text { dipengaruhi } \\
\text { oleh kedalaman } \\
\text { benda pada } \\
\text { fluida. }\end{array}$ & $\begin{array}{l}\text { Perhatikan gambar tabung berisi air di bawah. } \\
\text { Jika dalam kondisi tersebut benda X memiliki tekanan hidrostatis } \\
\text { Px maka tekanan hidrostatis yang lebih besar dimiliki oleh ... } \\
\text { volume fluida ditambahkan dan titik X tetap berada pada posisi } \\
\text { awal sehingga kedalaman titik X bertambah. }(k) \\
\text { memindahkan titik X pada bejana yang lebih sempit namun } \\
\text { meletakkan titik X pada kedalaman yang sama yaitu } 4 \mathrm{~cm} .\left(m_{3}\right) \\
\text { memindahkan titik X pada bejana yang lebih luas namun } \\
\text { meletakkan titik X pada kedalaman yang sama yaitu } 4 \mathrm{~cm} .\left(m_{2}\right) \\
\text { mengganti letak titik X mendekati permukaan fluida, sehingga } \\
\left.\text { posisi titik X lebih jauh dari dasar fluida. ( } m_{1}\right) \\
\text { Alasan: } \\
\text { Semakin jauh dari dasar wadah atau semakin tinggi kedudukan } \\
\text { benda semakin besar pula tekanan hidrostatisnya. }\left(m_{1}\right) \\
\text { Semakin dalam kedudukan benda dari permukaan fluida semakin } \\
\text { besar pula tekanan hidrostatisnya. }(k) \\
\text { Semakin luas permukaan wadah maka semakin besar pula tekanan } \\
\text { hidrostatisnya. ( } m_{2} \text { ) } \\
\text { Semakin sempit permukaan wadah maka semakin besar tekanan } \\
\text { hidrostatisnya. ( } m_{3} \text { ) } \\
\text { Apakah anda yakin? } \\
\text { Yakin } \\
\text { Tidak yakin } \\
\text { Berapa besar keyakinan anda? } \\
10 \text { - } 7 \\
6 \text { - } 4 \\
3 \text {-0 }\end{array}$ \\
\hline
\end{tabular}




\begin{abstract}
Jika disajikan gambar 4 titik yang tercelup pada wadah berisi air dengan bentuk bagian atasnya lebih kecil dari pada bawahnya, siswa dapat menentukan besarnya tekanan hidrostatis dipengaruhi oleh kedalaman benda pada fluida. Empat buah titik tercelup dalam fluida seperti pada gambar dibawah ini!

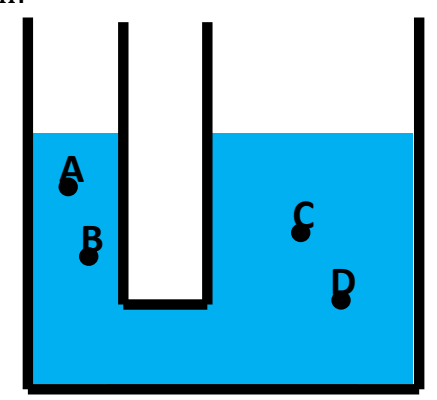

Berdasarkan gambar tersebut, pernyataan di bawah ini yang tepat adalah...

tekanan hidrostatis pada titik A dan B sama besar serta lebih besar dari pada tekanan hidrostatis pada titik $\mathrm{C}$ dan $\mathrm{D}\left(\mathrm{m}_{3}\right)$

tekanan hidrostatis pada titik A dan B sama besar serta lebih kecil dari pada tekanan hidrostatis pada titik C dan $\mathrm{D}\left(\mathrm{m}_{2}\right)$

tekanan hidrostatis paling besar adalah pada titik A dibandingkan dengan titik B, C, dan D $\left(m_{1}\right)$

tekanan hidrostatis paling besar adalah pada titik $\mathrm{D}$ dibandingkan dengan titik $\mathrm{A}, \mathrm{B}$, dan $\mathrm{C}(k)$

Alasan:

Semakin jauh dari dasar wadah atau semakin tinggi kedudukan benda semakin besar pula tekanan hidrostatisnya. $\left(m_{1}\right)$

Semakin dalam kedudukan benda dari permukaan fluida semakin besar pula tekanan hidrostatisnya. $(k)$

Penampang wadah yang lebih besar mengakibatkan tekanan hidrostatisnya lebih kecil. $\left(m_{3}\right)$

Penampang wadah yang lebih besar mengakibatkan tekanan hidrostatisnya lebih besar pula. $\left(m_{2}\right)$

Apakah anda yakin?

Yakin

Tidak yakin

Berapa besar keyakinan anda?

$10-7$

$6-4$

$3-0$

Butir soal tersebut divalidasi dan direvisi berdasarkan saran dari ahli. Butir soal yang telah dinyatakan layak oleh ahli akan diimplementasikan pada subjek coba. Butir soal yang digunakan untuk implementasi diacak sehingga tidak berurutan pada 3 butir soal yang setara.
\end{abstract}

Hasil validasi disajikan pada Tabel 3.

Tabel 3. Hasil validasi instrumen diagnostik three-tier

\begin{tabular}{l|l|l|l}
\hline No & Ranah & $\begin{array}{l}\text { Rentangan Nilai } \\
\text { Rata-rata }\end{array}$ & Keeterangan \\
\hline 1 & Materi & $3,42-3,75$ & Layak \\
\hline 2 & Konstruksi & $3,42-3,67$ & Layak \\
\hline 3 & Bahasa & $3,40-3,60$ & Layak \\
\hline 4 & Kemampuan Identifikasi Miskonsepsi & $3,33-4,00$ & Layak \\
\hline
\end{tabular}




\subsection{Analisis Data Hasil Identifikasi Konsepsi}

Hasil konsepsi siswa berdasarkan tes menggunakan instrumen diagnostik three-tier kemudian diidentifikasi berdasarkan kategorinya. Terdapat empat kategori kondisi konsepsi siswa yaitu: (1) siswa yang memiliki konsepsi benar, (2) siswa yang lemah dalam penguasaan konsepsi, (3) siswa yang mengalami miskonsepsi, dan (4) siswa yang tidak memiliki konsepsi. Hasil identifikasi konsepsi siswa pada materi fluida statis dibedakan dalam 3 konsep yaitu pada konsep tekanan hidrostatis, tekanan tambahan dalam fluida (pascal), dan gaya Archimedes. Hasil identifikasi konsepsi siswa disajikan pada Tabel 4 .

Tabel 4. Hasil Identifikasi Konsepsi Siswa

\begin{tabular}{|c|c|c|c|c|c|c|c|c|c|}
\hline \multirow{3}{*}{ No } & \multirow{3}{*}{ Indikator } & \multicolumn{8}{|c|}{ Jawaban Siswa } \\
\hline & & \multicolumn{2}{|c|}{$\begin{array}{l}\text { Konsepsi } \\
\text { benar }\end{array}$} & \multicolumn{2}{|c|}{$\begin{array}{l}\text { Lemah } \\
\text { konsepsi }\end{array}$} & \multicolumn{2}{|c|}{$\begin{array}{l}\text { Mis } \\
\text { Konsepsi }\end{array}$} & \multicolumn{2}{|c|}{$\begin{array}{l}\text { Tidak } \\
\text { memiliki } \\
\text { konsepsi }\end{array}$} \\
\hline & & $\Sigma$ & $\%$ & $\Sigma$ & $\%$ & $\Sigma$ & $\%$ & $\Sigma$ & $\%$ \\
\hline \multicolumn{10}{|c|}{ Konsep: tekanan hidrostatis } \\
\hline 1. & $\begin{array}{l}\text { menjelaskan } \\
\text { tekanan hidrostatis } \\
\text { dipengaruhi } \\
\text { kedalaman benda. }\end{array}$ & 6 & 23.1 & 2 & 7.7 & 6 & 23.1 & 12 & 46.2 \\
\hline 2. & $\begin{array}{l}\text { menjelaskan } \\
\text { tekanan hidrostatis } \\
\text { pada satu garis } \\
\text { horizontal adalah } \\
\text { sama besar. }\end{array}$ & 3 & 11.5 & 2 & 7.7 & 10 & 38.5 & 11 & 42.3 \\
\hline 3. & $\begin{array}{l}\text { menjelaskan } \\
\text { tekanan hidrostatis } \\
\text { sebanding dengan } \\
\text { massa jenis fluida. }\end{array}$ & 10 & 38.5 & 3 & 11.5 & 5 & 19.2 & 8 & 30.8 \\
\hline \multicolumn{2}{|c|}{ JUMLAH } & 19 & 73.1 & 7 & 26.9 & 21 & 80.8 & 31 & 119.3 \\
\hline & Rata & 6.3 & 24.4 & 2.3 & 9.0 & 7.0 & 26.9 & 10.3 & 39.8 \\
\hline \multicolumn{10}{|c|}{ Konsep: tekanan tambahan dalam fluida (Pascal) } \\
\hline 4. & $\begin{array}{l}\text { menentukan } \\
\text { besarnya tekanan } \\
\text { tambahan yang } \\
\text { diberikan pada } \\
\text { fluida. }\end{array}$ & 5 & 19.2 & 0 & 0 & 8 & 30.8 & 13 & 50 \\
\hline 5 & $\begin{array}{l}\text { menentukan } \\
\text { besarnya gaya tekan } \\
\text { sebanding dengan } \\
\text { luas permukaan } \\
\text { bidang tekan. }\end{array}$ & 4 & 15.4 & 4 & 15.4 & 8 & 30.8 & 10 & 38.5 \\
\hline \multicolumn{2}{|c|}{ JUMLAH } & 9 & 34.6 & 4 & 15.4 & 16 & 61.6 & 23 & 88.5 \\
\hline & & 4.5 & 17.3 & 2.0 & 7.7 & 8.0 & 30.8 & 11.5 & 44.3 \\
\hline \multicolumn{10}{|c|}{ Konsep: gaya Archimedes } \\
\hline 6. & $\begin{array}{l}\text { menjelaskan gaya } \\
\text { Archimedes pada } \\
\text { benda yang tercelup } \\
\text { seluruhnya pada } \\
\text { fluida adalah sama } \\
\text { besar karena massa } \\
\text { jenis fluida sama dan }\end{array}$ & 7 & 26.9 & 4 & 15.4 & 8 & 30.8 & 7 & 26.9 \\
\hline
\end{tabular}




\begin{tabular}{|c|l|l|c|c|c|c|c|c|c|}
\hline & $\begin{array}{l}\text { tidak dipengaruhi } \\
\text { kedalaman benda. }\end{array}$ & & & & & & & & \\
\hline 7. & $\begin{array}{l}\text { menjelaskan gaya } \\
\text { Archimedes pada } \\
\text { benda yang tercelup } \\
\text { dipengaruhi volume } \\
\text { benda yang tercelup. }\end{array}$ & 6 & 23.1 & 4 & 15.4 & 9 & 34.6 & 7 & 26.9 \\
\hline 8. & $\begin{array}{l}\text { menjelaskan faktor } \\
\text { yang mempengaruhi } \\
\text { kedudukan benda } \\
\text { yang tercelup dalam } \\
\text { fluida. }\end{array}$ & 5 & 19.2 & 1 & 3.8 & 10 & 38.5 & 10 & 38.5 \\
\hline JUMLAH & 18 & 69.2 & 9 & 34.6 & 27 & 103.9 & 24 & 92.3 \\
\hline \multicolumn{2}{|l|}{ Rata-Rata } & 6.0 & 23.1 & 3.0 & 11.5 & 9.0 & 34.6 & 8.0 & 30.8 \\
\hline
\end{tabular}

Berdasarkan data hasil identifikasi konsepsi pada Tabel 4 menunjukkan bahwa dari 26 siswa, kondisi konsepsi siswa terbesar adalah pada siswa yang tidak memiliki konsepsi dan siswa yang mengalami miskonsepsi. Siswa yang tidak memiliki konsepsi berada pada rentang 30,8\% - 44,3\% dan siswa yang mengalami miskonsepsi berada pada rentang $26,9 \%-34,6 \%$. Ini merupakan madalah besar dalam dunia pendidikan yang harus segera diatasi. Setiap siswa dalam kondisi yang berbeda perlu mendapatkan penanganan yang spesifik sesuai kondisi konsepsi dalam pikirannya.

Analisis konsepsi siswa berdasarkan hasil tes juga digunakan untuk mengidentifikasi jenis miskonsepsi pada materi fluida statis yang dialami oleh siswa. Jenis miskonsepsi fluida statis yang dialami subjek coba dalam penelitian ini ditunjukkan pada Tabel 5 .

Tabel 5. Jenis Miskonsepsi yang Dialami Subjek Coba

\begin{tabular}{|c|c|c|c|}
\hline Indikator & Jenis Miskonsepsi Siswa & $\Sigma$ & $\%$ \\
\hline \multicolumn{4}{|c|}{ Konsep : tekanan hidrostatis } \\
\hline \multirow{3}{*}{1} & $\begin{array}{l}\text { Siswa beranggapan bahwa tekanan hidrostatis berbanding } \\
\text { lurus dengan ketinggian }\left(\mathrm{m}_{1}\right)\end{array}$ & 2 & 7.7 \\
\hline & $\begin{array}{l}\text { Siswa beranggapan bahwa tekanan berbanding lurus } \\
\text { dengan luas penampang wadah }\left(\mathrm{m}_{2}\right)\end{array}$ & 1 & 3.8 \\
\hline & $\begin{array}{l}\text { Siswa beranggapan bahwa tekanan berbanding terbalik } \\
\text { dengan luas penampang wadah }\left(\mathrm{m}_{3}\right)\end{array}$ & 3 & 11.5 \\
\hline \multirow{2}{*}{2} & $\begin{array}{l}\text { Siswa beranggapan bahwa tekanan hidrostatis akan lebih } \\
\text { besar pada bejana yang tertutup }\left(\mathrm{m}_{2}\right)\end{array}$ & 2 & 7.7 \\
\hline & $\begin{array}{l}\text { Siswa beranggapan bahwa tekanan hidrostatis dipengaruhi } \\
\text { kedalaman benda dari sisi atas masing-masing bejana }\left(\mathrm{m}_{3}\right)\end{array}$ & 8 & 30.8 \\
\hline \multirow{3}{*}{3} & $\begin{array}{l}\text { Siswa beranggapan bahwa tekanan hidrostatis berbanding } \\
\text { terbalik dengan massa jenis fluida }\left(\mathrm{m}_{1}\right)\end{array}$ & 1 & 3.8 \\
\hline & $\begin{array}{l}\text { Siswa beranggapan bahwa tekanan hidrostatis berbanding } \\
\text { lurus dengan massa jenis benda }\left(\mathrm{m}_{2}\right)\end{array}$ & 3 & 11.5 \\
\hline & $\begin{array}{l}\text { Siswa beranggapan bahwa tekanan hidrostatis berbanding } \\
\text { terbalik dengan massa jenis benda }\left(\mathrm{m}_{3}\right)\end{array}$ & 1 & 3.8 \\
\hline \multicolumn{4}{|c|}{ Konsep: tekanan tambahan dalam fluida (Pascal) } \\
\hline 4 & $\begin{array}{l}\text { Siswa beranggapan bahwa tekanan berbanding terbalik } \\
\text { dengan luas penampang }\left(\mathrm{m}_{1}\right)\end{array}$ & 1 & 3.8 \\
\hline
\end{tabular}




\begin{tabular}{|c|c|c|c|}
\hline & $\begin{array}{l}\text { Siswa beranggapan bahwa tekanan berbanding lurus } \\
\text { dengan luas penampang }\left(\mathrm{m}_{2}\right)\end{array}$ & 5 & 19.2 \\
\hline & $\begin{array}{l}\text { Siswa beranggapan bahwa gaya yang bekerja pada luas } \\
\text { penampang akan diteruskan kesegala arah sama besar } \\
\text { gaya yang bekerja pada luas penampang akan diteruskan } \\
\text { kesegala arah sama besar }\left(\mathrm{m}_{3}\right)\end{array}$ & 2 & 7.7 \\
\hline \multirow{3}{*}{5} & $\begin{array}{l}\text { Siswa beranggapan bahwa gaya yang bekerja pada piston } 1 \\
\text { tidak mempengaruhi piston } 2 \text { dan hanya dipengaruhi gaya } \\
\text { yang bekerja pada masing-masing piston }\left(\mathrm{m}_{1}\right)\end{array}$ & 1 & 3.8 \\
\hline & $\begin{array}{l}\text { Siswa beranggapan bahwa gaya tekan berbanding terbalik } \\
\text { dengan luas permukaan bidang tekan dan semakin luas } \\
\text { bidang tekannya semakin kecil gayanya karena tekanan } \\
\text { pada dua sisi piston adalah sama besar }\left(\mathrm{m}_{2}\right)\end{array}$ & 2 & 7.7 \\
\hline & $\begin{array}{l}\text { Siswa beranggapan bahwa gaya yang dikerjakan pada luas } \\
\text { penampang akan diteruskan oleh fluida ke seluruh bagian } \\
\text { piston sama besar }\left(\mathrm{m}_{3}\right)\end{array}$ & 5 & 19.2 \\
\hline \multicolumn{4}{|c|}{ Konsep: gaya Archimedes } \\
\hline \multirow{3}{*}{6} & $\begin{array}{l}\text { Siswa beranggapan bahwa gaya Archimedes berbanding } \\
\text { lurus dengan kedalaman benda }\left(\mathrm{m}_{1}\right)\end{array}$ & 3 & 11.5 \\
\hline & $\begin{array}{l}\text { Siswa beranggapan bahwa gaya Archimedes berbanding } \\
\text { terbalik dengan kedalaman benda }\left(\mathrm{m}_{2}\right)\end{array}$ & 4 & 15.4 \\
\hline & $\begin{array}{l}\text { Siswa beranggapan bahwa gaya Archimedes pada dasar } \\
\text { bejana adalah nol }\left(\mathrm{m}_{3}\right)\end{array}$ & 1 & 3.8 \\
\hline \multirow[b]{2}{*}{7} & $\begin{array}{l}\text { Siswa beranggapan bahwa gaya Archimedes pada benda } \\
\text { yang tercelup dipengaruhi massa benda }\left(\mathrm{m}_{1}\right)\end{array}$ & 6 & 23.1 \\
\hline & $\begin{array}{l}\text { Siswa beranggapan bahwa gaya Archimedes pada benda } \\
\text { yang tercelup dipengaruhi gaya-gaya yang bekerja pada } \\
\text { benda tersebut }\left(\mathrm{m}_{2}\right)\end{array}$ & 3 & 11.5 \\
\hline \multirow{3}{*}{8} & $\begin{array}{l}\text { Siswa beranggapan bahwa kedudukan benda dalam fluida } \\
\text { bergantung pada perbandingan massa benda dan massa } \\
\text { fluida }\left(\mathrm{m}_{1}\right)\end{array}$ & 2 & 7.7 \\
\hline & $\begin{array}{l}\text { Siswa beranggapan bahwa kedudukan benda dalam fluida } \\
\text { bergantung pada perbandingan tekanan pada bagian atas } \\
\text { benda dan tekanan pada bagian bawah benda }\left(\mathrm{m}_{2}\right)\end{array}$ & 1 & 3.8 \\
\hline & $\begin{array}{l}\text { Siswa beranggapan bahwa kedudukan benda dalam fluida } \\
\text { bergantung pada perbandingan gaya Archimedes dan berat } \\
\text { benda }\left(\mathrm{m}_{3}\right)\end{array}$ & 7 & 26.9 \\
\hline
\end{tabular}

\section{Simpulan}

\subsection{Kesimpulan}

Berdasarkan uraian hasil penelitian dan pembahasan pengembangan instrumen diagnostik three-tier untuk mengidentifikasi miskonsepsi siswa kelas X MIA menunjukkan bahwa instrumen yang digunakan telah layak berdasarkan hasil validasi ahli. Instrumen yang dihasilkan telah dinyatakan layak dan mampu untuk mengidentifikasi miskonsepsi siswa pada materi fluida statis. Produk ditinjau dari segi butir soal sudah baik dan layak karena setiap rumusan soal mampu mengumpulkan bentuk-bentuk konsepsi yang salah dari siswa. Produk ditinjau dari segi pilihan jawaban dapat dikatakan baik karena mampu membuat siswa berpikir untuk menjawab setiap butir soal. produk ditinjau dari segi kemampuan identifikasi miskonsepsi sudah baik dan layak dengan ditunjukkan dari hasil analisis validasi isi oleh ahli memberikan nilai rata-rata pada rentang 3,33-4,00. 
Berdasarkan hasil analisis menunjukkan bahwa dari 26 siswa pada subjek coba masih banyak siswa berada pada kondisi mengalami miskonsepsi dan tidak memiliki konsepsi. Jenis miskonsepsi pada materi fluida statis yang dialami subjek coba pun cukup beragam.Oleh sebab itu, permasalahan ini perlu menjadi perhatian dalam dunia pendidikan, sehingga kondisi konsepsi siswa yang tidak benar dapat diatasi sesuai masalahnya masing-masing.

\subsection{Saran} berikut.

Berdasarkan hasil penelitian yang diperoleh, maka dapat disarankan sebagai

Adanya penelitian dan pengembangan lebih lanjut terhadap instrumen diagnostik three-tier yang telah dikembangkan.

Hasil identifikasi miskonsepsi yang telah dilakukan kepada subjek coba dapat ditindaklanjuti sehingga siswa-siswa yang masih belum memiliki konsepsi yang benar mendapatkan penanganan yang tepat.

Instrumen diagnostik three-tier dapat dikembangkan dengan memberikan pilihan jawaban terbuka sehingga siswa dapat menuliskan konsepsinya jika dirasa konsepsi-konsepsi yang disediakan pada pilihan jawaban tidak sesuai dengan konsepsi yang ada dalam pikirannya dan juga perlu dikembangkan pada materi yang lain.

Hasil analisis menunjukkan bahwa siswa yang dinyatakan tidak memiliki konsepsi masih cukup besar, padahal siswa tersebut telah memperoleh pembelajaran tentang materi tersebut. Hal ini diharapkan dapat menjadi perhatian dalam dunia pendidikan, sehingga perlu evaluasi lebih lanjut tentang pelaksanaan pembelajaran dalam kelas.

\section{Daftar Rujukan}

Arikunto, S. (2012). Dasar-dasar evaluasi pendidikan edisi 2. Jakarta: Bumi Aksara.

Barke, H. D., Hazari, A., \& Yitbarek, S. (2009). Misconceptions in chemistry: Addressing perceptions in chemical education by Springer-Verlag: Berlin.

Danks, S. (2011). The ADDIE model: Designing, evaluating instructional coach effectiveness. ASQ Primary and Secondary Education Brief, 4(5), 1-6.

Demirci, N. (2005). A Study about Students' Misconceptions in Force and Motion Concepts by Incorporating a Web-Assisted Physics Program. Turkish Online Journal of Educational Technology-TOJET, 4(3), 40-48.

Goszewski, M., Moyer, A., Bazan, Z., \& Wagner, D. J. (2013, January). Exploring student difficulties with pressure in a fluid. In AIP Conference Proceedings (Vol. 1513, No. 1, pp. 154-157). American Institute of Physics.

Smith, S. R., \& Abell, S. K. (2008). Assessing and addressing student science ideas. Science and Children, 45(7), 72.

Wagner, D. J., Carbone, E., \& Lindow, A. (2013). Exploring student difficulties with buoyancy. PERC Proceedings, Pubished by the American Association of Physics Teachers under a Creative Commons Attribution. 